\title{
IDENTIFYING FACTORS THAT AFFECT THE ACCEPTANCE AND USE OF E-ASSESSMENT BY ACADEMICS IN SAUDI UNIVERSITIES
}

\author{
Nuha Alruwais ${ }^{1}$, Gary Wills ${ }^{2}$ and Mike Wald ${ }^{3}$ \\ ${ }^{1} \mathrm{PhD}$ student, University of Southampton, nma1g14@soton.ac.uk \\ ${ }^{2}$ Dr., University of Southampton, gbw@ecs.soton.ac.uk \\ ${ }^{3}$ Prof., University of Southampton, mw@ecs.soton.ac.uk
}

\begin{abstract}
As assessment is one of the important pillars of the learning process, and E-assessment has become an essential part of education systems. E-assessment has developed to address some of the limitations and problems of a paper-test. In last the10 years, E-assessment has improved in developed countries such as the UK. In contrast, in Saudi Arabia, one of the developing countries, less attention has been paid to the usage of E-assessment and research which discusses E-assessment issues in Saudi Arabia is limited. Consequently, we investigate the factors that impact on academic's use of E-assessment in Saudi universities. In order to examine these factors, the Decomposed Theory of Planned Behavior model (DTPB) is adopted with slight modification. Age and gender are added to the proposed model as moderating factors that affect attitude, subjective norms and perceived behavioral control. IT support is also added as a subfactor under perceived behavioral control and technology facilitating conditions are included under resources facilitating conditions.
\end{abstract}

Keywords: E-assessment, E-exam, electronic exam, online exam, online assessment.

\section{INTRODUCTION}

Learning begins at an early age in human life, and assessment is considered as a vital part of learning (Gilbert, Whitelock, \& Gale, 2011). Assessment is a measure used to evaluate the performance and progress of an individual (Llamas-Nistal et al., 2013). Assessment based on using information technology, known as "E-assessment", has become one of the systems introduced to address some problematic issues in traditional assessment. E-assessment has successfully provided direct results and feedback, reducing the tutor's time and effort, facilitating the assessment of problem-solving, and improving student performance (Gilbert et al., 2011; Ridgway et al., 2004; Crews \& Curtis, 2010; Way, 2012; Gikandi et al., 2011; Sorensen, 2013).

Research into E-assessment applications has been increasing in some countries to gain more understanding of their impacts on the education sector. The UK government has been increasing the usage of Eassessment in a very aspirational project (Ridgway et al., 2004). From the 1990s, the Joint Information System Committee (JISC) in the UK has recognized the importance of E-assessment in the UK education 
sector, and the requirements of research and education communities in this area (McGill, 2006). JISC supports many research studies and projects in E-assessment in the UK. As a result, a large number of research studies have been initiated to cover E-assessment issues in UK.

In contrast, in Saudi Arabia, the focus region of this study, there has been a shortage of research studies that investigate $\mathrm{E}$-assessment issues. One of these issues is the acceptance and usage of $\mathrm{E}$-assessment in Saudi Universities. This study will investigate the factors that impact on academics acceptance and use of Eassessment in Saudi universities.

\section{LITERETURE REVIEW}

The use of technology in assessment began in the 1920s', when Sidney Pressey designed a machine for automatic testing (Skinner, 1958). Moreover, at the same time the schools started to use standardised assessment, and automatic scoring technology, which helped to make large-scale testing convenient and cost-effective (Audette, 2005).

A massive change in many sectors, especially in education, occurred when the World Wide Web was introduced in the 1990's (Llamas-Nistal et al., 2013). From that time onwards, many companies introduced their own E-assessment system. In England, Wales and Northern Ireland principles and guidance for Eassessment were introduced by JISC (Joint Information System Committee) to clarify the different qualifications regulators in the United Kingdom (JISC, 2007). In 2009 the IMS Global Learning Consortium produced the IMS Question and Test interoperability Specification (IMS, 2008). In 2009 Cisco, Intel and Microsoft produced Transforming Education: Assessing and Teaching $21^{\text {st }}$ Century Skills (Cisco, Intel \& Microsoft, 2009).

Since the introduction of E-learning and E-assessment, the learning process has developed, E-assessment has enhanced the measurement of learner outcomes and made it possible to obtain immediate and direct feedback (Gilbert et al., 2011). This enables an assessment system to be created, which takes into account the educational goals and helps students to develop their skills which will be useful for the society in the long-term (Ridgway et al., 2004). JISC (2007) defines E-assessment as the end-to-end electronic assessment process, where ICT (Information Communication Technology) is used for the whole assessment processes from the presentation of questions to the saving of the learners' responses. E-assessment has advantages compared with paper-test, in terms of saving time consumed for the tutor to correct each paper (Crews \& Curtis, 2010; Donovan et al., 2007; Eljinini \& Alsamarai, 2012; Gikandi, Morrow, \& Davis, 2011; Gilbert et al., 2011; Ridgway et al., 2004; Sorensen, 2013). For example, in study at Leeds Metropolitan University it was found that E-assessment saved up to $£ 3000$ per cohort in staff time (Gilbert et al., 2011). Eassessment also provides immediate feedback, which helps to enhance learning (Crews \& Curtis, 2010; Gilbert et al., 2011; Ridgway et al., 2004; Way, 2012). Moreover, it can help students in remote areas to learn and be assessed in their own locations and assessment test can be taken at any time, providing flexibility for the students (Ridgway et al., 2004; Gilbert \& Gale, 2007; Williams \& Wong, 2009; Way, 2012).

\section{E-ASSESSMENT IN SAUDI UNIVERSITIES}

The Saudi population has significantly increased, and half of this population is under university age. There are about one million students enrolled at these universities and colleges, whereas in 1970 there were only 7000 students enrolled (Royal Embassy of Saudi Arabia in Washington, 2015). As a result, thousands of students are left without a place at university. Therefore, to introduce technology into education, the National Centre for E-learning and Distance Learning (NCEDL) was established in 2006, under the management of the Higher Education Ministry, to offer E-learning courses throughout the Kingdom (Almegran, Al-Yafei, \& Ahmad, 2007). According to Madar Research, the Saudi government spent USD 125 million in 2008 to set up the E-learning system (Gazette, 2008).

This centre provides nationwide E-learning development in the universities with the assistance of the Open University in Malaysia and Multimedia Technology Enhancement Operations (Almegran et al., 2007). It is, also, responsible for research and development to facilitate E-learning in higher education, which includes the National Learning Management System (Jusur), and the National Repository (Maknaz) to save, manage, and share learning objects between Saudi universities (Alkhalifa, 2010; Al-fahad, 2009). Furthermore, NCEDL operates a project call Tajseer (in English: Bridging), that helps to improve the traditional methods of teaching and learning using technology (Alkhalifa 2010; Al-fahad, 2009).

The Saudi government has integrated E-learning and E-assessment systems within its educational systems (both in schools and higher education) (Hakami et al., 2014). However, while there are many studies about E-learning in Saudi Arabia (Alebaikan \& Troudi, 2010; Al-fahad, 2009; Alkhalaf, Drew, \& Alhussain, 2012; 
Almegran et al., 2007; Al-Shehri, 2010; Malek \& Karim, 2010; Mirza, 2007; Yushau, 2006), few of these studies mention E-assessment. Moreover, there is no research which has investigated the factors that impact on the use of E-assessment by academics in Saudi universities. Therefore, this study attempts to identify the factors that affect the academics' willingness to accept and use E-assessment.

\section{MODELS OF USER ACCEPTANCE AND USE OF ICT}

Many researchers and practitioners have attempted to introduce and explain a theoretical perspective for a user's acceptance and use of ICT. For example, the Theory of Reasoned Action (TRA) (Fishbein \& Ajzen, 1975), Theory of Planned Behaviour (TPB) ( Ajzen, 1985), Technology Acceptance Model (TAM) (Davis, 1985), and the Decomposed Theory of Planned Behaviour (DTPB) (Taylor \& Todd 1995).

DTPB, which is similar to TAM is used for predicting users' intentional behaviour towards using technology. This model was created by, Taylor \& Todd (1995) to address the weaknesses of TPB, on which it was based. DTPB identifies salient beliefs that may affect adoption and use of technology, which can be used across different settings (Taylor \& Todd 1995; Ejaz 2014). In this model Taylor \& Todd (1995) retain the three determinants of behavioural intention present in the TPB: attitude, subjective norm and perceived behavioural control (Figure.1). However, they decompose the determinant 'attitude' into three elements: perceived usefulness, perceived ease of use and compatibility. This model is a combination of the best elements of TAM and TPB (Mathieson, Peacock, \& Chin, 2001). Furthermore, the decomposition of these beliefs within one model (DTPB); make it able to predict the behaviour under investigation as well as having the power to provide explanations (Shih \& Fang, 2004). As a result, the model becomes more valuable, understandable and applicable (Ejaz, 2014).

Figure.1 Decomposed Theory of Planned Behaviour (DTPB) (Taylor \& Todd, 1995)

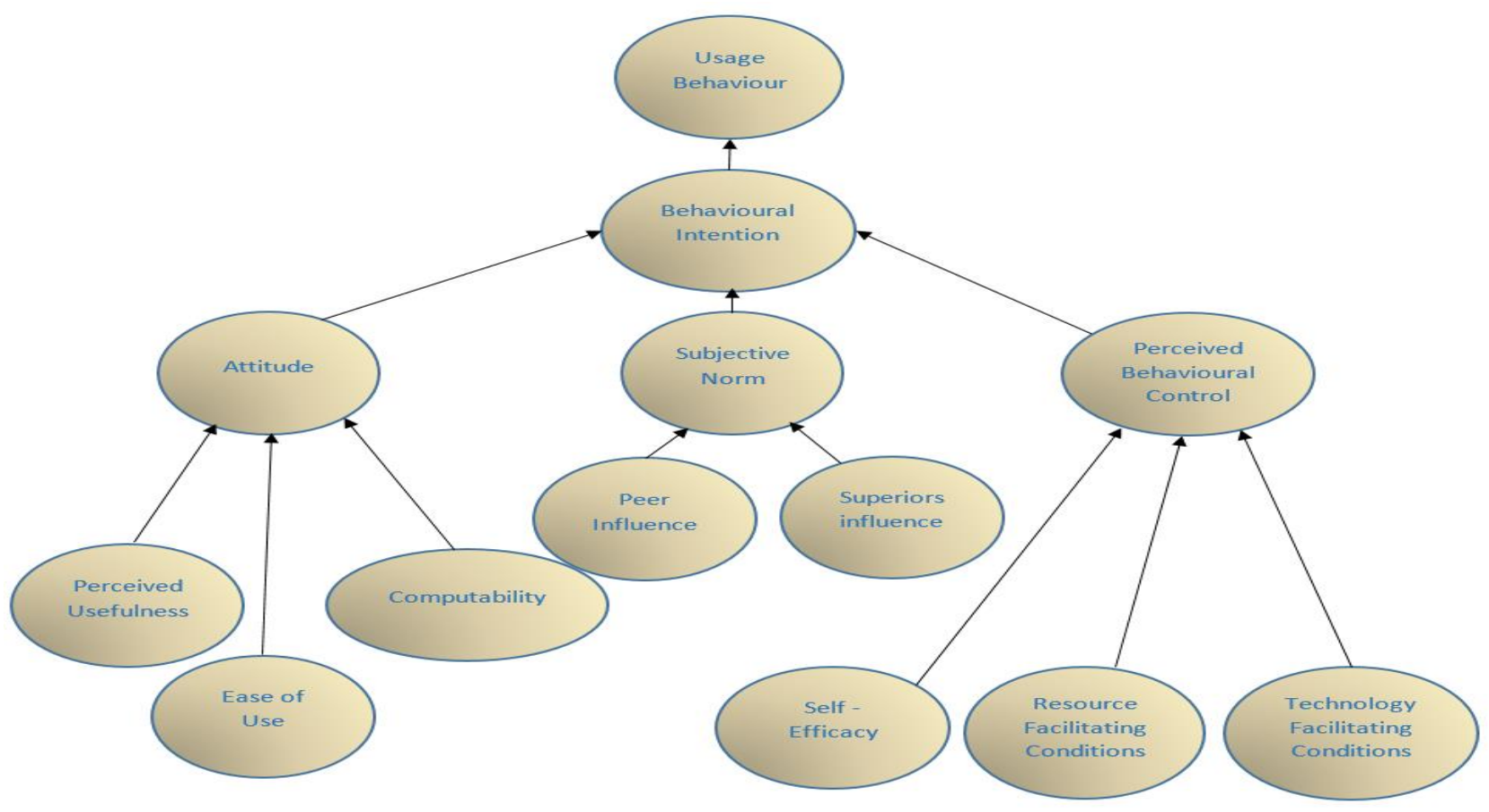

The DTBP model includes the most significant factors that can affect user behavioural intention towards using ICT. It also provides a complete picture to understand user behavioural intention to accept and use ICT. Figure. 2 illustrates the three models (TAM, TPB, DTPB) and shows how the DTPB contains all the important factors from both the TAM and TPB models (Chien, Wu, \& Hsu, 2014). In addition, Table.1 shows the factors in each model that were considered, in order to select the best model which would include the main factors that may have an impact on the use of E-assessment by lecturers in Saudi universities. 
Figure. 2 TAM, TPB and DTPB (Chien et al., 2014)

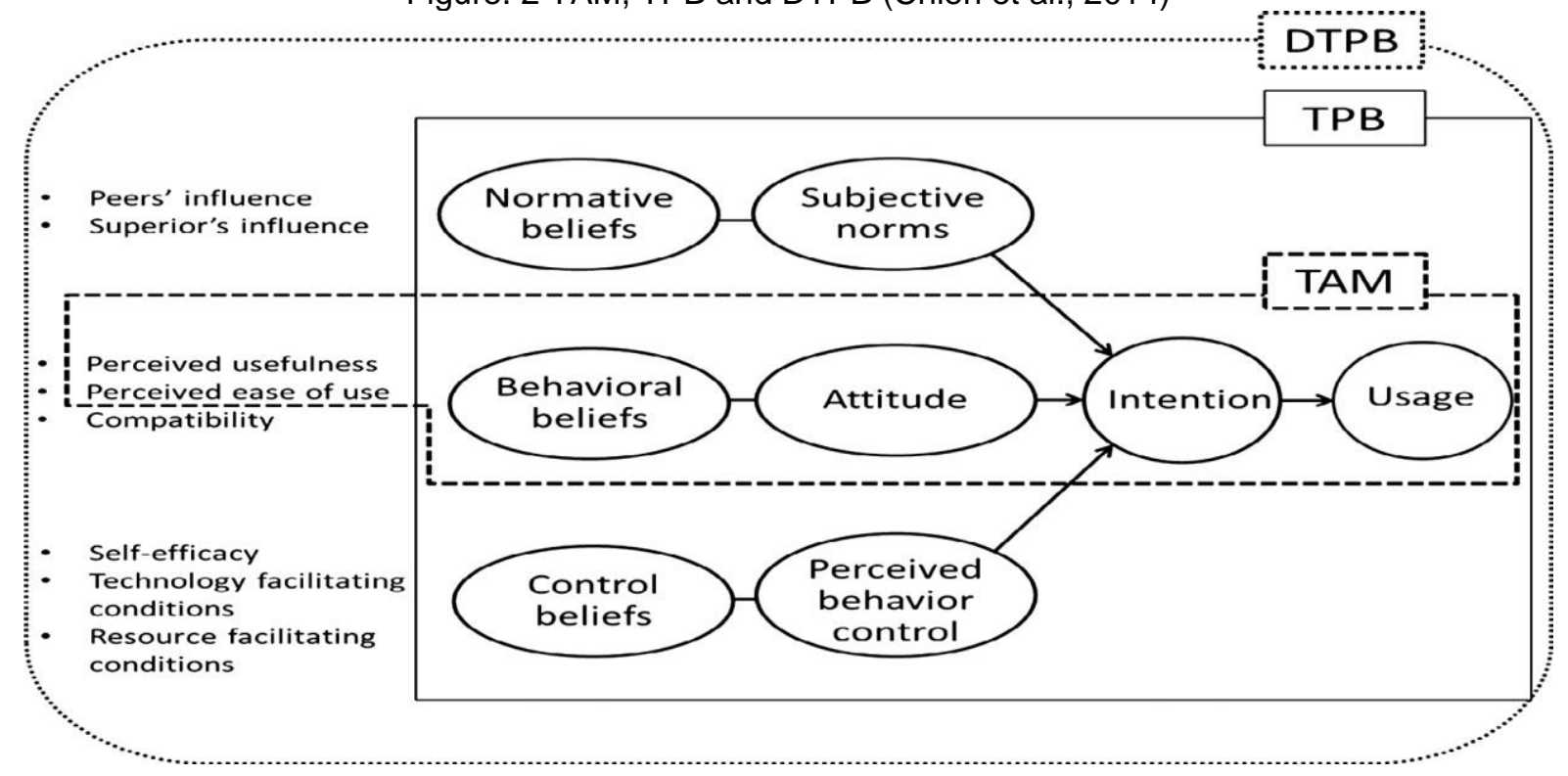

Table. 1 Table.1 Factors in each model

\begin{tabular}{|c|c|c|c|c|c|c|c|c|c|c|c|}
\hline \multirow[t]{2}{*}{$\begin{array}{l}\text { Models/ } \\
\text { factors }\end{array}$} & \multicolumn{3}{|c|}{$\begin{array}{c}\text { Subjective Norms } \\
\text { (SN) }\end{array}$} & \multicolumn{4}{|c|}{ Attitude } & \multicolumn{4}{|c|}{$\begin{array}{l}\text { Perceived Behavioural } \\
\text { Control(PBC) }\end{array}$} \\
\hline & z & 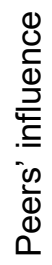 & 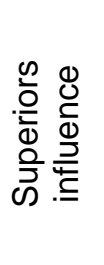 & $\begin{array}{l}\frac{0}{0} \\
\frac{P}{+} \\
\frac{1}{4}\end{array}$ & 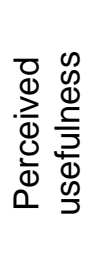 & 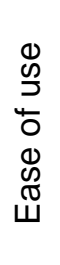 & 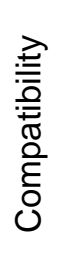 & $\begin{array}{l}\text { O } \\
\square \\
\alpha\end{array}$ & 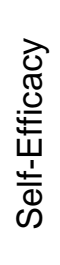 & 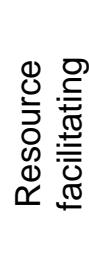 & 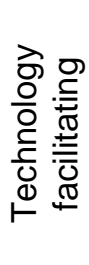 \\
\hline TAM & $\bar{x}$ & $x$ & $x$ & $\sqrt{ }$ & $\sqrt{ }$ & $\sqrt{ }$ & $x$ & $x$ & $x$ & $x$ & $x$ \\
\hline TPB & $\sqrt{ }$ & $x$ & $x$ & $\sqrt{ }$ & $x$ & $x$ & $x$ & $\sqrt{ }$ & $x$ & $x$ & $x$ \\
\hline DTPB & $\sqrt{ }$ & $\sqrt{ }$ & $\sqrt{ }$ & $\sqrt{ }$ & $\sqrt{ }$ & $\sqrt{ }$ & $\sqrt{ }$ & $\sqrt{ }$ & $\sqrt{ }$ & $\sqrt{ }$ & $\sqrt{ }$ \\
\hline
\end{tabular}

The DTPB model has been used widely in research to explain individuals' behaviour towards using technology (Ejaz, 2014). Many studies have applied DTPB in different domains, including: finance, business and education (Ejaz, 2014). In the education domain, Chien et al. (2014) used the DTPB model to investigate teachers' intention to use technology-based assessments and their actual use. They found that the DTPB model can describe and predict the actual usage of a system. Sadaf et al. (2012); also; explored teachers' intentions to use Web 2.0 technology in their classrooms, and found that the three constructs (attitude, subjective norm and perceived behavioural control) had a significant impact on the teachers' intentions. Consequently, this study adopted the DTPB model, with some editing, to produce the Model of Acceptance and Usage of E-assessment to examine the acceptance and utilisation of E-assessment by academics in Saudi universities. This model includes all the factors in DTPB except technology facilitating conditions, which is transferred to resource facilitating conditions. This is because technology is considered as one of the resources (Taylor \& Todd, 1995) . IT support is added as a factor under perceived behavioural control, because some studies have stressed the importance of availability of IT staff to support lecturers and students when using E-assessment (Eljinini \& Alsamarai, 2012; Sitthiworachart, Joy, \& Sutinen, 2008; Way, 2012). Age and gender are added in this study as moderating factors, because some studies have provided evidence that age and gender impact attitude, subjective norm and perceived behavioural control (Venkatesh et al., 2000; Morris \& Venkatesh, 2000; Venkatesh et al., 2003). The Model of Acceptance and Usage of E-assessment (Figure. 3) which has been developed will enable the factors that impact academics' intention towards using E-assessment in Saudi universities to be investigated. Moreover, this model will enable the strongest factors, that affect the usage of E-assessment in Saudi universities to be identified, and will clarify the relationships between these factors. 
Figure. 3 The Model of Acceptance and Usage of E-assessment (MAUE)

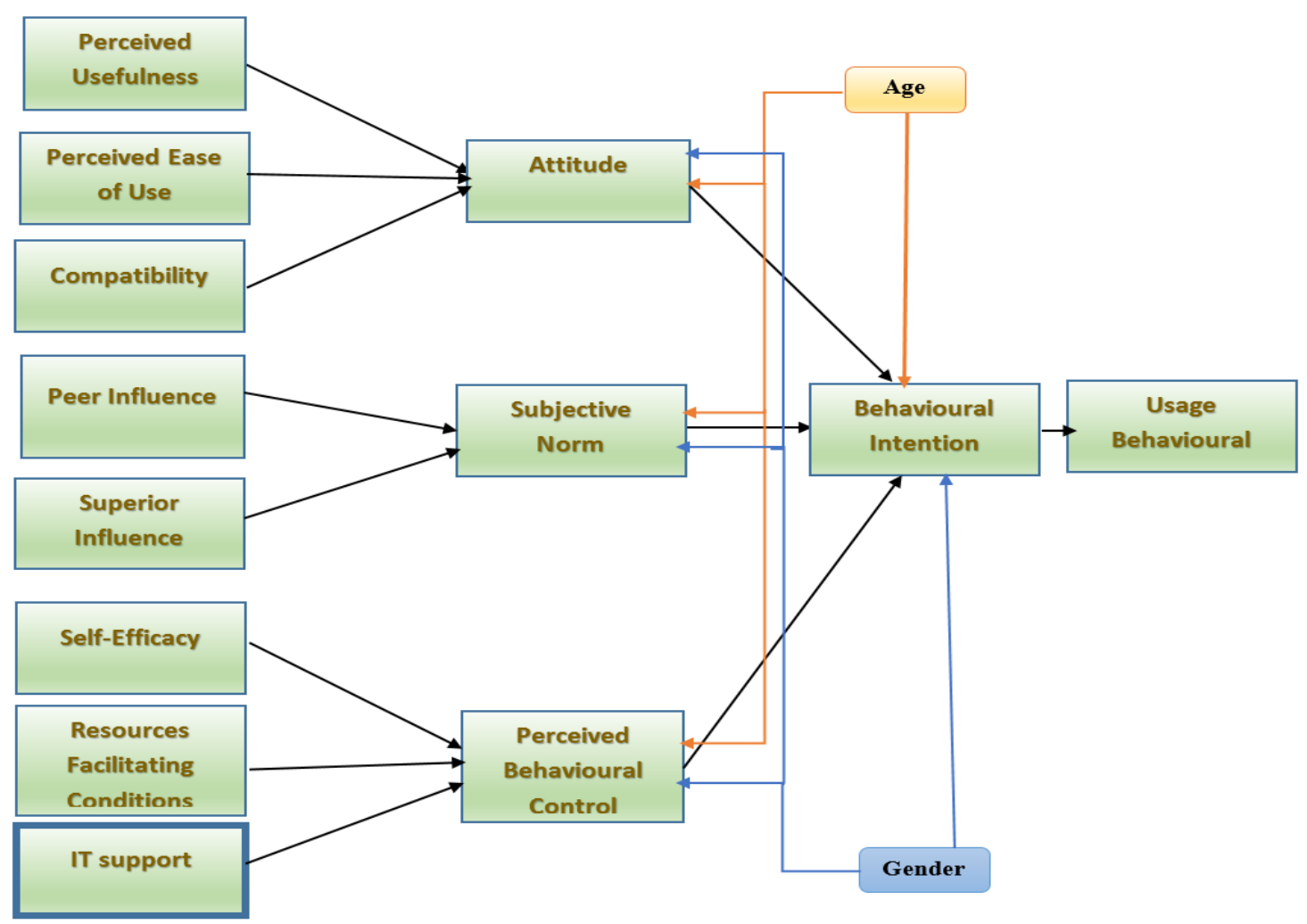

\section{The MODEL OF ACCEPTANCE AND USAGE OF E-ASSESSMENT}

The conceptual model of this study is shown in Figure 3. It consists of the constructors described in the following sections:

\subsection{Behavioural Intention}

This is the degree to which the individual intends to perform or not perform certain behaviour (Fishbein \& Ajzen, 1975). It is divided into three determinants: attitude, subjective norm and perceived behavioural control.

\subsubsection{Attitude}

This means the positive or negative evaluation indicated by the individual in respect to undertaking certain behaviour (Ajzen, 2005). It is decomposed into three sub-factors:

I. Perceived usefulness: This is the degree to which the person believes that using a specific system will enhance his/her performance (Davis, 1989). In this study it is used to mean the belief that using $\mathrm{E}$ assessment for a member of the academic staff will enhance his/her performance. Perceived usefulness is an important factor that can indicate user intention to use technology (Anandarajan, Igbaria, \& Anakwe, 2002; Ghorab, 1997).

II. Perceived ease of use: This is defined as the degree to which using a specific system will not require an effort (Davis, 1989). In the current study it is used to mean that if the E-assessment does not need more effort and is easy to use, the member of staff is likely to accept and use it. Davis (1989) stresses the importance of this factor in user technology acceptance. Other studies have indicated that perceived ease of use plays a key role in user intention to accept new technology (Anandarajan et al., 2002; Ghorab, 1997).

III. Compatibility: This is the degree to which the current system matches past experience and current requirements of the user (Moore \& Benbasat, 1991). To motivate lecturers to use E-assessment, it should fit with the lecturers' needs and their past. 


\subsubsection{Subjective norm}

This is defined as the individual perception, which is influence by other people, towards performing particular behaviour (Fishbein \& Ajzen, 1975). Subjective norm addresses the impact of social influences. It consists of two sub-factors:

I. Peer influence: This is defined as the effect of family, friends and peers on individual intention to perform certain behaviour (Ajzen \& Fishbein, 1980). In this study, peer influence means the impact of the opinions of other on lecturers in their intention to use of E-assessment.

II. Supervisors' influence: This means the influence of the supervisor such as the Head of School, in encouraging lecturers to use E-assessment.

\subsubsection{Perceived behavioural control}

According to Ajzen (1991) perceived behavioural control "refers to people's perception of the ease or difficulty of performing the behaviour of interest". In other words, the user should have control over the influences that may affect performing certain behaviour. This construct is decomposed into three sub-factors:

I. Self-efficacy: This is defined as the degree to which the individual has the ability to perform specific behaviour (Todd \& Model, 1995). It is important that lecturers feel that they have the ability to use E-assessment and be confident to deal with it. Some studies have highlighted the effectiveness of self-efficacy in users accepting technology (Compeau, Higgins, \& Huff, 1999; Taylor \& Todd, 1995b).

II. Resource facilitating conditions: This influence includes the external factors that affect a user's decision to perform particular behaviour (Ejaz, 2014). According to Taylor \& Todd (1995) resource facilitating conditions include sufficient time, money and technology, and if one of these resources is inadequate or absent that will impact the user's technology acceptance. Thus, lecturers should have adequate time to use this form of assessment, and also have access to the money and technology needed to use E-assessment. Eljinini \& Alsamarai (2012) found that the availability of infrastructure impacts the success of E-assessment implementation. The importance of the infrastructure factor in establishing an E-assessment system is also highlighted by Way (2012).

III. IT support: This is defined as the presence of supportive IT staff who help lecturers to use Eassessment and design flexible E-assessment applications. The successful implementation of Eassessment depends on supporting IT staff to enable them to provide training courses (Sitthisak, Gilbert, \& Davis, 2008), and to implement the system correctly (Eljinini \& Alsamarai, 2012; Way, 2012).

\subsection{Moderating Factors}

I. Gender: The gender can affect attitude, subjective norm and perceived behavioural control (Morris \& Venkatesh, 2000; Viswanath Venkatesh et al., 2003). Researchers have pointed that there are differences between males and females, and the male tends to be more highly taskoriented (Minton \& W. Schneider, 1980).

II. Age: The age of an individual has an influence on attitude, subjective norm and perceived behavioural control (Morris \& Venkatesh, 2000; Venkatesh et al., 2003). Morris \& Venkatesh (2000) point out that its effect on attitude is more noticeable for younger users, whereas its effect on perceived behaviour control is more noticeable for older users.

\section{FUTURE WORK}

To validate the Model of Acceptance and Usage of E-assessment, the next step will be to interview 10 - to 15 experts to ensure that they agree that these are the factors likely to have an influence on lecturers' use of Eassessment. This step will also be used to check whether there are other factors that may affect lecturers' intention to use E-assessment. These experts will be a group consisting of: heads of deanships E-learning, E-assessment experts, and the electronic service supporters. Later, the result of the interviews will be analysed, in order to identify the factors that are thought to really affect E-assessment usage. Subsequently, a questionnaire will be designed and delivered to lecturers from different universities from Saudi Arabia, to validate these factors and identify the factors which have a strong effect on the lecturers' intention to use Eassessment. 


\section{ACKNOWLEDGEMENT}

This research is supported by the University of Southampton, and the Fundamental Research Funds for Saudi Culture Mission in UK. Their support and consideration are highly appreciated.

\section{REFERENCE LIST}

Ajzen, I. (1985). From Intentions to Actions: A Theory of Planned Behavior. In Action Control (1st ed., pp. 11-39). Berlin Heidelberg: Springer.

Ajzen, I. (1991). The theory of planned behavior. Orgnizational Behavior and Human Decision Processes, $50,179-211$.

Ajzen, I. (2005). Attitudes, Personality, and Behavior. McGraw-Hill International. Retrieved from http://books.google.co.uk/books?hl=en\&lr=\&id=ZbDIAAAAQBAJ\&oi=fnd\&pg=PP1\&dq=Attitudes, + Pers onality, +and+Behavior\&ots=hr_b4vcnbH\&sig=gDd4yFNRh4KIgJlJxoEFqnqGQog\#v=onepage\&q=Attit udes $\% 2 \mathrm{C}$ Personality\%2C and Behavior\&f=true

Ajzen, I., \& Fishbein, M. (1980). Understanding Attitudes and Predicting Social Behaviour. Prentice-Hall.

Alebaikan, R., \& Troudi, S. (2010). Blended learning in Saudi universities: challenges and perspectives. Alt$J, 18(1), 49-59$.

Al-fahad, F. N. (2009). Students' Attitudes and Perceptions Towards The Effectiveness of Mobile Learning in King Saud University, Saudi Arabia. The Turkish Online Journal of Educational Technology- TOJET, $8(2)$.

Alkhalaf, S., Drew, S., \& Alhussain, T. (2012). Assessing the Impact of e-Learning Systems on Learners: A Survey Study in the KSA. Procedia - Social and Behavioral Sciences, 47, 98-104.

Alkhalifa, H. (2010). E-learning and ICT Integration in Colleges and Universities in Saudi Arabia. Retrieved February 25, 2015, from http://elearnmag.acm.org/featured.cfm?aid=1735849

Almegran, A., Al-Yafei, A., \& Ahmad, H. (2007). Pilot nationwide e-learning provision in the Kingdom of Saudi Arabia: Issues and challenges. In 21st Asian Association of Open Universities' Annual Conference. Kuala Lumpur, Malaysia. Retrieved from http://eprints.oum.edu.my/13/

Al-Shehri, A. M. (2010). E-learning in Saudi Arabia: "To E or not to E, that is the question." Journal of Family and Community Medicine, 17(3), 147-150.

Anandarajan, M., Igbaria, M., \& Anakwe, U. P. (2002). IT acceptance in a less-developed country: A motivational factor perspective. International Journal of Information Management, 22, 47-65.

Audette, B. (2005). Beyond curriculum alignment: How one high school is using student assessment data to drive curriculum and instruction decision making, (2001). Retrieved from https://castl.duq.edu/Conferences/Library03/PDF/Dat_Driv_Dec/Audette_B.pdf

Chien, S. P., Wu, H. K., \& Hsu, Y. S. (2014). An investigation of teachers' beliefs and their use of technology-based assessments. Computers in Human Behavior, 31, 198-210.

Compeau, D., A. Higgins, C., \& Huff, S. (1999). Social Cognitive Theory and Individual Reactions To Computing Technology: a Longitudinal Study. MIS Quarterly, 23(2), 145-158.

Crews, T. B., \& Curtis, D. F. (2010). Online Course Evaluations: Faculty Perspective and Strategies for Improved Response Rates. In Assessment \& Evalution in Higher Education (Vol. 36, pp. 965-878). Routledge.

Davis, F. D. (1985). A technology acceptance model for empirically testing new end-user information systems: Theory and results. (Doctoral dissertation, Massachusetts Institute of Technology).

Davis, F. D. (1989). Perceived Usefulness, Perceived Ease of Use, and User Acceptance of Information Technology, MIS quarterly, 13(3), 319-340.

Donovan, J., Mader, C., \& Shinsky, J. (2007). Online vs. traditional course evaluation formats: Student perceptions. Journal of Interactive Online Learning, 6, 158-180. Retrieved from http://www.ncolr.org/jiol/issues/pdf/6.3.2.pdf

Ejaz, A. (2014). Analysis of motivational factors influencing acceptance of technologically-enhanced personal , academic and professional development portifilos. (Doctoral dissertation, University of Huddersfield 
Repository).

Eljinini, M., \& Alsamarai, S. (2012). The Impact of E-assessments system on the success of the implementation process. Modern Education and Computer Science, 4(11), 76-84.

Fishbein, M., \& Ajzen, I. (1975). Belief, attitude, intention, and behavior: an introduction to theory and research. Reading, MA: Addison-Wesley.

Gazette. (2008). Business: Kingdom's e-learning industry to reach \$ 125 milion this year. Retrieved March 1, 2015, from:

http://www.saudigazette.com.sa/index.cfm?method=home.regcon\&contentID=200804244097

Ghorab, K. E. (1997). The impact of technology acceptance considerations on system usage, and adopted level of technological sophistication: An empirical investigation. International Journal of Information Management, 17(4), 249-259.

Gikandi, J. W., Morrow, D., \& Davis, N. E. (2011). Online formative assessment in higher education: A review of the literature. Computers \& Education, 57(4), 2333-2351.

Gilbert, L., Whitelock, D., \& Gale, V. (2011). Synthesis Report on Assessment and Feedback with Technology Enhancement. University of Southampton.

Hakami, Y., Razak, A., Husin, C., \& Tam, S. (2014). A CBT Framework For Secondary Schools of Saudi. Sci.Int. (1), 853-864.

IMS, G. L. Consortium. (2008). IMS Question \& test Interoperability specification. Retrieved February 10, 2015, from http://www.imsglobal.org/question/

Llamas-Nistal, M., Fernández-Iglesias, M. J., González-Tato, J., \& Mikic-Fonte, F. A. (2013). Blended eassessment: Migrating classical exams to the digital world. Computers \& Education, 62, 72-87.

Malek, A., \& Karim, A. (2010). An Empirical Investigation into The Role of Enjoyment, Computer Anxiety, Computer Self-Efficacy and Internet Experience in Influencing the Students' Intention to Use Elearning: A Case Study from Saudi Arabian Governmental Universities. Turkish Online Journal of Educational Technology-TOJET, 9(4), 22-34.

Mathieson, K., Peacock, E., \& Chin, W. W. (2001). Extending the technology acceptance model: The influence of perceived user resources. Database for Advances in Information Systems, 32(3), 86-112.

McGill, L. (2006). Overview of JISC assessment activities. In 10th CAA International Computer Assissted Assessment Conference: Proceedings of the Conference 4th and 5th July 2006 at Loughborough University (pp. 309-312). Loughborough: Loughborough University. Retrieved from http://caaconference.co.uk/pastConferences/2006/proceedings/McGill_L_p1.pdf

Minton, H. L., \& W. Schneider, F. (1980). Differential psychology. Waveland PressInc.

Mirza, A. (2007). Is e-learning finally gaining legitimacy in Saudi Arabia. Saudi Computer Journal, 6(2).

Moore, G., \& Benbasat, I. (1991). Development of an instrument to measure the perceptions of adopting an information technology innovation. Information Systems Research.

Morris, M. G., \& Venkatesh, V. (2000). Age differences in technology adoption decisions : Implications for a changing work force. Personnel Psychology, 53(2), 375-403.

M: Ministry of Education and Planning, (Saudi Arabia) (2007). Population and Housing Characteristics in the Kingdom of Saudi Arabia: Demographic Survey 1428H.

Ridgway, J., McCusker, S., \& Pead, D. (2004). Literature review of e-assessment. (Vol. 44). UNSPECIFIED. Futurelab, Bristol. Retrieved from http://dro.dur.ac.uk/1929/

Sadaf, A., Newby, T. J., \& Ertmer, P. a. (2012). Exploring pre-service teachers' beliefs about using Web 2.0 technologies in K-12 classroom. Computers and Education, 59(3), 937-945.

Shih, Y.-Y., \& Fang, K. (2004). The use of a decomposed theory of planned behavior to study Internet banking in Taiwan. Internet Research, 14(3), 213-223.

Sitthisak, O., Gilbert, L., \& Davis, H. C. (2008). An evaluation of pedagogically informed parameterised questions for self-assessment. Learning, Media and Technology, 33(3), 235-248.

Sitthiworachart, J., Joy, M., \& Sutinen, E. (2008). Success Factors for E-assessment in Computer science 
Education. Advancement of Computing in Education, 4, 2287-2293.

Skinner, B. F. (1958). Teaching Machines. Science, 128(3330), 969-977.

Sorensen, E. (2013). Implementation and student perceptions of e-assessment in a Chemical Engineering module. European Journal of Engineering Education, 38(2), 172-185.

Taylor, S., \& Todd, P. (1995a). Decomposition and crossover effects in the theory of planned behavior: A study of consumer adoption intentions. International Journal of Research in Marketing, 12, 137-155.

Taylor, S., \& Todd, P. A. (1995b). Understanding information technology usage: A test of competing models. Information Systems Research. MIS quarterly. 6(2), 144-176.

Todd, P., \& Model, T. A. (1995). Assessing IT Usage : The Role of Prior Experience The Influence of Prior Experience, 19(4), 561-570.

Venkatesh, V., Davis, F. D., \& College, S. M. W. (2000). Theoretical Acceptance Extension Model: Field Four Studies of the Technology Longitudinal. Management Science, 46(2), 186-204.

Venkatesh, V., \& Morris, G. M. (2000). Why don't men ever stop to ask for directions? Gender, social influence and their role in technology acceptance and usage behaviour. MIS Quarterly, 24(1), 115139.

Venkatesh, V., Morris, M. G., Davis, G. B., \& Davis, F. D. (2003). User Acceptance of Information Technology: Towards a Unified View1. Management Information System Research Center, University of Minnesota, 27(3), 425-478.

Way, A. (2012). The Use of E-assessments in The Nigerian Higher Education System. Turkish Online Journal of Distance Education, 13(1), 140-152.

Williams, J. B., \& Wong, A. (2009). The efficacy of final examinations: A comparative study of closed-book, invigilated exams and open-book, open-web exams. British Journal of Educational Technology, 40(2), 227-236.

Yushau, B. (2006). The Effects of Blended E-Learning on Mathematics and Computer Attitudes in PreCalculus Algebra. TMME, 3(2), 176-183. 